\title{
FEDERALISMO FISCAL, AUTONOMIA FINANCEIRA E COOPERAÇÃO FEDERATIVA: UM OLHAR SOBRE A POSSIBILIDADE DE INSTITUIÇÃO DE UM IMPOSTO SOBRE O VALOR AGREGADO NO BRASIL A PARTIR DAS CONSEQUÊNCIAS DO "PODER DE NÃO TRIBUTAR"
}

\section{FISCAL FEDERALISM, FINANCIAL AUTONOMY AND FEDERATIVE COOPERATION: A VIEW ON THE POSSIBILITY OF INTRODUCTION OF A VALUE-ADDED TAX IN BRAZIL FROM THE CONSEQUENCES OF THE "POWER TO NOT TAX"}

Maria Laura Clemente Morais Universidade Federal de Juiz de Fora Graduada em Direito Juiz de Fora/MG. Brasil. marialcmorais@outlook.com

iD Elizabete Rosa de Mello Universidade Federal de Juiz de Fora Doutora em Direito

Professora Adjunta da Faculdade de Direito da UFJF. Juiz de Fora/MG. Brasil. elizabeterosademello@gmail.com

Resumo: Discute-se, há muito, a necessidade de uma alteração substancial no Sistema Tributário Nacional. Dentre as propostas de reforma, destaca-se a instituição de um imposto único sobre o consumo nos moldes de um imposto sobre o valor agregado (IVA), à qual parte da doutrina resiste, em virtude da crença de que tal medida violaria o pacto federativo ao promover uma concentração da competência tributária, o que reduziria a autonomia dos entes da Federação. Neste artigo, pretende-se demonstrar que, ao contrário, a adoção de um IVA, a depender do desenho a ele conferido pelo legislador, pode fortalecer a autonomia financeira dos entes federativos, tendo em vista o cenário atual de práticas excessivas de renúncia fiscal, oportunizado pelo amplo poder de não tributar. Emprega-se uma metodologia crítico-dialética, com amparo em pesquisas de ordem qualitativa e quantitativa, com consulta a material bibliográfico e a dados disponibilizados online por instituições públicas.

Palavras-chave: federalismo fiscal; tributação do consumo; IVA.

\begin{abstract}
Among the proposals for a reform of the national tax, those that aim to establish a single tax with the features of a value-added tax (VAT), in substitution of the various taxes on consumption, are noteworthy. Part of the doctrine understands that such a measure would be incompatible with fiscal federalism, since it would reduce the tax jurisdiction of the States, Federal District and Municipalities. This paper aims to demonstrate that, on the contrary, the adoption of a VAT, depending on its shape given by the lawmaker, could strengthen the financial autonomy of the federative entities, given the current scenario of excessive tax breaks, made possible by the large power to not tax. It is employed a critical-dialectic methodology, based on the results of qualitative and quantitative research, with reference to bibliographic materials and data made available online by public institutions.
\end{abstract}

Keywords: fiscal federalism; taxation on consumption; value-added tax.

\section{Para citar este artigo (ABNT NBR 6023:2018)}

MORAIS, Maria Laura Clemente; MELLO, Elizabete Rosa de. Federalismo fiscal, autonomia financeira e cooperação federativa: um olhar sobre a possibilidade de instituição de um imposto sobre o valor agregado no Brasil a partir das consequências do "poder de não tributar". Revista Thesis Juris - RTJ, São Paulo, v. 10, n. 1, p. 16-44, jan./jun. 2021. http://doi.org/10.5585/rtj.v10i1.16962. 
MORAIS, Maria Laura Clemente; MELLO, Elizabete Rosa de. Federalismo fiscal, autonomia financeira e cooperação federativa: um olhar sobre a possibilidade de instituição de um imposto sobre o valor agregado no Brasil a partir das consequências do "poder de não tributar"

\section{Introdução}

O Sistema Tributário Nacional, estabelecido pela Constituição da República Federativa do Brasil de 1988 (CRFB/1988), promove a tributação sobre o consumo a partir da distribuição de competências tributárias entre os entes da Federação. Em virtude da complexidade e do caráter obsoleto desse modelo, que provocam reflexos na arrecadação, discute-se com frequência a necessidade de uma reforma substancial no modo de se tributar o consumo. Dentre as propostas de alteração, destaca-se a instituição de um imposto único nos moldes de um imposto sobre o valor agregado ou adicionado (IVA). Além de simplificar a atividade fiscal, sua base tributável alargada permitiria uma incidência mais ampla da exação, especialmente no que concerne às novas tecnologias, que desafiam a tradicional distinção entre mercadorias e serviços adotada pela legislação tributária brasileira. Ademais, sua implantação combateria as guerras fiscais, questão especialmente acentuada entre os Estados-membros, além de possivelmente promover um impacto positivo na receita dos entes federativos, por restringir a renúncia fiscal.

Entretanto, em razão de a medida implicar modificações profundas na distribuição de competências tributárias entre os membros da Federação, questiona-se sua compatibilidade com o pacto federativo. Segundo parte da doutrina - e.g. Piscittelli (2017), Harada (2018) -, a instituição de um IVA com seu perfil tradicional comprometeria a autonomia financeira dos entes federativos, pois ensejaria um processo de concentração da atividade tributária e, consequentemente, uma maior dependência de um ente em relação ao outro. Com o intuito de se afastar esse pretenso óbice, o presente estudo promove uma reanálise do papel dos mecanismos de promoção do federalismo fiscal, quais sejam, o poder de tributar - que engloba não apenas a competência tributária, mas também a capacidade tributária ativa - e a repartição de receitas, a partir da relação entre a concessão excessiva de benefícios fiscais e alguns dos desafios da tributação sobre o consumo no Brasil.

$\mathrm{Na}$ seção 1, são apresentados os tributos atualmente incidentes sobre o consumo, evidenciando-se a complexidade do modelo vigente e os desafios dele advindos. Analisam-se com maior profundidade dois desses desafios, que possuem uma maior conexão com o pacto federativo, quais sejam, o fenômeno das guerras fiscais e o superendividamento dos entes da Federação, com enfoque na situação dos Estados-membros. Em seguida, na seção 2, discorrese sobre as características tradicionais de um IVA, que o tornam uma alternativa à estrutura vigente no Brasil. Por fim, a seção 3 trata diretamente do federalismo fiscal. Propõe-se um novo olhar sobre os mecanismos de promoção da autonomia financeira dos entes federativos, 
MORAIS, Maria Laura Clemente; MELLO, Elizabete Rosa de. Federalismo fiscal, autonomia financeira e cooperação federativa: um olhar sobre a possibilidade de instituição de um imposto sobre o valor agregado no Brasil a partir das consequências do "poder de não tributar"

expondo-se suas fragilidades e virtudes e, ainda, relacionando-os à necessidade de cooperação entre os membros da Federação.

Com amparo em pesquisa de natureza teórica, descritiva e bibliográfica, são expostos conceitos doutrinários pertinentes ao tema. A metodologia empregada é a crítico-dialética, com o fim de examinar o objeto de estudo (compatibilidade de um IVA com o pacto federativo) à luz de uma interpretação crítica do conteúdo bibliográfico já produzido.

\section{Tributação sobre o consumo no Brasil e os desafios do modelo atual}

Os impostos incidentes sobre o consumo são aqueles cujos fatos geradores correspondem à produção e à circulação de riquezas (TORRES, 2007). Não contemplam substancialmente o princípio da capacidade contributiva (artigo 145, § $1^{\circ}$, CRFB/1988), uma vez que, à exceção da compra de mercadorias consideradas de luxo, não refletem significativamente o poderio econômico do contribuinte de fato, o consumidor ${ }^{1}$. Nesse grupo, estão os impostos sobre produtos industrializados (IPI) - previsto no artigo 153, inciso IV, da CRFB/1988, de competência da União -, sobre operações relativas à circulação de mercadorias e sobre prestações de serviços de transporte interestadual e intermunicipal e de comunicação (ICMS) - artigo 155, inciso II, de competência dos Estados-membros e do Distrito Federal - e sobre serviços de qualquer natureza (ISSQN) - artigo 156, inciso III, de competência dos Municípios e do Distrito Federal.

O IPI possui três hipóteses de incidência definidas no artigo 46 do Código Tributário Nacional (CTN), quais sejam, “[...] a) desembaraçar produtos industrializados de origem estrangeira; b) realizar operação com produtos industrializados; e c) arrematar produtos industrializados apreendidos ou abandonados" (COSTA, 2017, p. 378). É um imposto seletivo (a alíquota varia conforme a essencialidade do produto) e não-cumulativo (não há a incidência em cascata ao longo da cadeia produtiva), (PAULSEN 2018).

A não-cumulatividade é característica também presente de forma compulsória no ICMS, nos termos do artigo 155, $\S 2^{\circ}$, inciso I, da CRFB/1988. Já a seletividade em função da essencialidade da mercadoria ou do serviço é, para este tributo, facultativa (artigo 155, $\S 2^{\circ}$, inciso III). Há diferentes fatos geradores desse imposto. Observa-se sua incidência, da leitura do artigo 155, inciso II, do texto constitucional, sobre “[...] a) operações relativas a circulação

\footnotetext{
${ }^{1}$ Os impostos incidentes sobre o consumo, de caráter indireto, não possuem fatos geradores conexos a manifestações de riqueza por excelência, como renda e patrimônio. Desse modo, uma reforma tendente a alterar apenas a estrutura da tributação sobre o consumo, ainda que apta a reduzir a complexidade do sistema e a otimizar o produto da arrecadação, não serve à promoção de uma maior justiça tributária sob a perspectiva do contribuinte de fato, pois não promove a valorização do princípio da capacidade contributiva. Essa discussão, contudo, não é objeto do presente artigo, o qual se limita a analisar a compatibilidade da instituição de um IVA com o pacto federativo.
} 
MORAIS, Maria Laura Clemente; MELLO, Elizabete Rosa de. Federalismo fiscal, autonomia financeira e cooperação federativa: um olhar sobre a possibilidade de instituição de um imposto sobre o valor agregado no Brasil a partir das consequências do "poder de não tributar"

de mercadorias; b) prestação de serviços de transporte interestadual e intermunicipal; c) prestação de serviços de comunicação [...]” e, do § $3^{\circ}$ do mesmo artigo, sobre “[...] d) produção, importação, circulação, distribuição ou consumo de lubrificantes e combustíveis líquidos e gasosos e de energia elétrica; e e) extração, circulação, distribuição ou consumo de minerais" (COSTA, 2017, p. 400).

As normas gerais do ICMS encontram-se na Lei Complementar $n^{\circ}$ 87/1996, por exigência constitucional estabelecida no artigo $155, \S 2^{\circ}$, inciso XII. Por ser um imposto de competência dos Estados-membros e do Distrito Federal, possui alíquotas variadas não apenas com relação a diferentes mercadorias, mas também em razão do local em que ocorre a operação, o que contribui para o estigma de um dos sistemas mais complexos do mundo que recai sobre a tributação do consumo no Brasil (GUIMARÃES, 2007). Tal complexidade é agravada pelos conflitos de competência com o ISSQN - imposto que, conforme já mencionado, cabe aos Municípios e ao Distrito Federal -, em virtude da crescente dificuldade de se diferenciarem mercadorias e serviços, dada a ampliação da economia digital.

O ISSQN é regulamentado pela Lei Complementar $n^{\circ} 116 / 2003$, a qual lista os serviços que configuram o fato gerador do tributo. A despeito de parte da doutrina entender que a competência dos Municípios e do Distrito Federal para a instituição do referido imposto se estende a todos os serviços não contemplados na hipótese de incidência do ICMS, a jurisprudência consolidou o entendimento de que restam excluídos os serviços não listados (COÊLHO, 2016).

Além dos impostos mencionados, a tributação sobre o consumo compreende a contribuição para o financiamento da seguridade social (COFINS) e o Programa de Integração Social (PIS), os quais, embora não incidam propriamente sobre a atividade consumerista, oneram o titular da atividade econômica (GUIMARÃES, 2007), sendo, por isso, contemplados por boa parte das propostas de reforma tributária no rol de tributos a serem substituídos pela figura de um imposto único, como na Emenda Substitutiva Global n ${ }^{\circ}$ 7/2018 à Proposta de Emenda à Constituição (PEC) no 293-A/2004. Ambos (COFINS e PIS) caracterizam-se como contribuições de seguridade social sobre a receita (PAULSEN, 2018). A COFINS foi instituída pela Lei $n^{\circ} 10.833 / 2003$, cujo artigo $1^{\circ}$ define sua incidência "[...] sobre o total das receitas auferidas no mês pela pessoa jurídica, independentemente de sua denominação ou classificação contábil” (BRASIL, 2003). Já o PIS foi instituído pela Lei Complementar $n^{\circ} 7 / 1970$, tendo sido unificado com o Programa de Formação do Patrimônio do Servidor Público (PASEP) pela Lei Complementar n 226/1975. 
MORAIS, Maria Laura Clemente; MELLO, Elizabete Rosa de. Federalismo fiscal, autonomia financeira e cooperação federativa: um olhar sobre a possibilidade de instituição de um imposto sobre o valor agregado no Brasil a partir das consequências do "poder de não tributar"

Verifica-se que o Brasil de fato possui uma complexa tributação sobre o consumo, o que, contudo, não é o único desafio que se impõe à legislação e à atividade tributárias. A expansão da economia digital, por exemplo, tem tornado mais árdua a distinção entre mercadorias e serviços, intensificando os conflitos de competência entre os Estados-membros (instituidores do ICMS) e os Municípios (aos quais cabe a instituição do ISSQN). Ademais, o modelo vigente permite a renúncia fiscal em excesso e, muitas vezes, indiscriminada, ocasionando as chamadas guerras fiscais e contribuindo de certa forma para o superendividamento dos entes da Federação. Estes dois últimos problemas merecem uma análise mais detalhada, por se relacionarem diretamente com o pacto federativo.

\subsection{Guerra fiscal}

Um dos instrumentos usualmente empregados pelos entes da Federação para a atração de investimentos é a concessão de benefícios fiscais ${ }^{2}$, o que, ao se verificar em demasia, tem intensificado o fenômeno da guerra fiscal, a qual "[...] é fundamentalmente um caso de concorrência fiscal predatória, [...] marcado pelo reiterado descumprimento, por parte de determinados entes federativos, do sistema legal e constitucionalmente previsto para a concessão de incentivos físcais [...]" (AFONSO et al., 2017, p. 418). Tal fenômeno é especialmente acentuado com relação ao ICMS, razão pela qual o tema será tratado com enfoque nos Estados-membros.

Há mecanismos constitucionais e infraconstitucionais que visam a inibir as disputas de natureza fiscal entre os entes (AFONSO et al., 2017), destacando-se o artigo 155, § $2^{\circ}$, inciso XII, alínea $g$, da CRFB/1988, o qual estabelece que cabe a lei complementar "regular a forma como, mediante deliberação dos Estados e do Distrito Federal, isenções, incentivos e benefícios fiscais serão concedidos e revogados" (BRASIL, 1988). Para cumprir a exigência constitucional, recepcionou-se a Lei Complementar $n^{\text {o }}$ 24/1975, que prevê a necessidade de celebração de convênios entre os Estados-membros para a concessão de isenções relativas ao ICMS.

Contudo, o que se verifica é um reiterado descumprimento dessa norma, tendo os Estados-membros, em termos práticos, ofertado diversos benefícios fiscais sem a observância do procedimento exigido pela legislação pertinente. Esse cenário conduziu à elaboração da Lei

\footnotetext{
${ }^{2}$ A legislação não define benefícios e incentivos fiscais. Contudo, costuma-se entender que os primeiros abrangem toda medida de caráter extrafiscal apta a desonerar o sujeito passivo da relação tributária, em nome do interesse público. Já os incentivos fiscais compreendem medidas de desoneração direcionadas a um fim específico (e.g. concessão de isenção do IPTU caso determinada sociedade empresária empregue um certo número de habitantes do Município). Percebe-se que o conceito de benefício fiscal engloba o de incentivo fiscal, sendo este espécie daquele (MELLO, 2013). Por essa razão, neste estudo, utiliza-se o termo benefícios fiscais como referência ampla a benefícios e incentivos.
} 
MORAIS, Maria Laura Clemente; MELLO, Elizabete Rosa de. Federalismo fiscal, autonomia financeira e cooperação federativa: um olhar sobre a possibilidade de instituição de um imposto sobre o valor agregado no Brasil a partir das consequências do "poder de não tributar"

Complementar no 160/2017, com o objetivo de regularizar as isenções e outros benefícios concedidos ilegalmente. O Convênio ICMS nº 190/2017, celebrado a partir da mencionada lei, dispõe sobre o modo como os Estados-membros podem proceder à remissão de créditos tributários referentes a benefícios fiscais concedidos em desconformidade com o artigo 155, $\S$ $2^{\circ}$, inciso XII, alínea $g$, da CRFB/1988. A despeito de dispensar um tratamento conciso à situação caótica já estabelecida, a Lei Complementar nº 160/2017 parece não ter a aptidão para de fato por fim à guerra fiscal (DOMENE, 2017), persistindo a possibilidade de perpetuação da má prática de concessão de benefícios fiscais sem atenção à exigência de acordo entre os Estados-membros por meio do instrumento adequado, qual seja, o convênio.

A desigualdade entre as regiões do país pode ser apontada como um dos fatores instigantes da guerra fiscal, na medida em que está “[...] se fortaleceu no gargalo provocado pelo próprio Estado, na ausência de instituições adequadas para fomentar o desenvolvimento regional, contornando as desigualdades intrínsecas à federação brasileira" (COLOMBO, 2017, p. 301). As renúncias fiscais se apresentam, portanto, como uma forma de os entes federativos, notadamente os Estados-membros, por sua própria atuação, buscarem reduzir seus problemas de ordem econômico-financeira, por meio da atração de investimentos para suas áreas. Ocorre que, por ser medida implantada isoladamente, ou seja, no âmbito de cada ente, sem a desejada cooperação, a concessão de benefícios fiscais, ao final, agrava as desigualdades regionais e, ainda, contribui para o superendividamento dos entes da Federação, tema a ser abordado na próxima subseção.

\subsection{Superendividamento dos entes federativos}

Os entes da Federação, sobretudo os Estados-membros, têm apresentado um quadro preocupante de superendividamento. Segundo análise conjuntural divulgada pelo Instituto de Pesquisa Econômica Aplicada (IPEA) em 2018, “Limitações da Lei de Responsabilidade Fiscal (ainda assim um instrumento fundamental) e interpretações idiossincráticas da legislação contribuíram para a crise das finanças públicas estaduais, que retratam um desequilíbrio de longo prazo entre receitas e despesas" (MORA et al., 2018, p.1).

Além de apontar fatores legais que colaboraram para o atual cenário de endividamento, o estudo enfatiza a ineficiência da arrecadação ao longo dos últimos anos, o que tem sido revertido tão somente a partir de 2017, supostamente em virtude de um aquecimento na economia do país. A pesquisa menciona, ainda, as medidas adotadas para a recuperação sobretudo dos Estados-membros, destacando-se a Lei Complementar $n^{\circ}$ 156/2016, que 
MORAIS, Maria Laura Clemente; MELLO, Elizabete Rosa de. Federalismo fiscal, autonomia financeira e cooperação federativa: um olhar sobre a possibilidade de instituição de um imposto sobre o valor agregado no Brasil a partir das consequências do "poder de não tributar"

estabeleceu o Plano de Auxílio aos Estados e ao Distrito Federal - possibilitando a renegociação da dívida em face da União até então disciplinada pelas Leis no 8.727/1993 e nº 9.496/1997 - e o refinanciamento de empréstimos tomados por dezoito Estados-membros junto ao Banco Nacional de Desenvolvimento Econômico e Social (BNDES), ao Banco do Brasil e à Caixa Econômica Federal (MORA et. al., 2018).

Embora a análise conjuntural do IPEA relacione a arrecadação deficitária tão somente ao cenário econômico do país e a distorções na interpretação da Lei de Responsabilidade Fiscal, é possível que aquela também tenha como causa, ainda que em menor grau, o excesso de renúncias fiscais. Dentre os Estados-membros em calamidade fiscal, sobressaem-se Minas Gerais e Rio de Janeiro (BRASIL, 2017), de ambos podendo ser extraídos exemplos de práticas irresponsáveis de concessão de benefícios fiscais.

No Relatório Portaria ${ }^{\circ}$ 80/PRES./2017, referente ao exercício financeiro de 2017, o Tribunal de Contas do Estado de Minas Gerais constatou o seguinte:

\begin{abstract}
Analisando o impacto das renúncias na execução orçamentária, infere-se que os Benefícios Heterônomos, os quais incidem apenas sobre o ICMS, correspondem a, aproximadamente, $15 \%$ de toda a receita arrecadada com esse tributo e a $9 \%$ da despesa corrente.

Focando somente nas renúncias consolidadas e novas, o destaque recai sobre sua equivalência em relação à despesa com Ações e Serviços Públicos de Saúde, que chegou a ser de 108,75\% no exercício de 2015, ou seja, o Estado deixou de arrecadar um valor 8,75\% maior que os gastos totais com Ações e Serviços Públicos de Saúde. Considerando a representatividade das renúncias concedidas, que superam os gastos do Estado de Minas Gerais na função saúde, deve-se destacar a ausência de registro contábil dos recursos que deixaram de ingressar nos cofres públicos, o que contraria a prática da gestão transparente e impossibilita a análise sistêmica do comportamento da política tributária do Estado frente à sua capacidade de arrecadação e alocação das receitas tributárias e não tributárias. Essa situação dificulta a aferição do fato de a política pública de desoneração fiscal praticada estar alcançando os objetivos de desenvolvimento social ou econômico (MINAS GERAIS, 2017, p. 20).
\end{abstract}

Percebe-se que, inobstante a significativa participação dos benefícios heterônomos (concedidos por meio da Lei Kandir e do SIMPLES Nacional) na renúncia fiscal, os benefícios concedidos pelo próprio Estado de Minas Gerais por si só têm agravado sua situação financeira, na medida em que, ao menos no exercício então analisado, deixou-se de demonstrar a consecução da finalidade da renúncia. Ressalte-se, ainda, o fato de que, no referido exercício financeiro, o total das renúncias fiscais foi superior aos gastos do Estado-membro com a saúde.

Quanto ao Estado do Rio de Janeiro, o Governo teve suas contas do exercício financeiro de 2016 previamente rejeitadas, dentre outras razões, pela ausência de transparência na concessão de benefícios fiscais: 
MORAIS, Maria Laura Clemente; MELLO, Elizabete Rosa de. Federalismo fiscal, autonomia financeira e cooperação federativa: um olhar sobre a possibilidade de instituição de um imposto sobre o valor agregado no Brasil a partir das consequências do "poder de não tributar"

[...] auditoria realizada na Companhia de Desenvolvimento Industrial do Estado CODIN detectou irregularidades relevantes na concessão de benefícios, como a ausência de estudo de impacto orçamentário-financeiro previamente à concessão de benefícios tributários, fruição irregular de benefícios fiscais, inexistência de acompanhamento estruturado e sistemático dos requisitos e contrapartidas das empresas beneficiárias de incentivos fiscais, ilegalidade no ato de concessão de benefícios fiscais, e ausência de transparência do processo decisório de concessão de benefícios fiscais (RIO DE JANEIRO, 2017, p. 40).

O superendividamento dos entes federativos (com destaque para os Estados-membros) tem como uma de suas consequências o agravamento da dependência financeira com relação à União. Mencione-se que os Estados de Minas Gerais e do Rio de Janeiro, além de outros, têm como maior credor o Tesouro Nacional (BRASIL, 2019). Desse modo, a concessão desmedida de benefícios fiscais, que guarda relação direta com o fenômeno da guerra fiscal e indireta com o superendividamento dos membros da Federação, compromete a própria autonomia financeira destes, questão tratada com maior profundidade na seção 3 deste artigo.

Os desafios impostos à atividade tributária - como a complexidade do sistema, seu caráter obsoleto perante a economia digital, as brechas legislativas que permitem guerras fiscais e as renúncias fiscais em demasia em um cenário de superendividamento - têm justificado a formulação de propostas de alteração substancial da tributação sobre o consumo, dentre as quais se destaca a instituição de um IVA. Desse modo, faz-se necessária a exposição das principais características desse imposto, a fim de se analisar, posteriormente, a sua compatibilidade com o federalismo fiscal.

\section{Perfil clássico de um imposto sobre o valor agregado}

O IVA, modelo mais recorrente de um imposto único sobre o consumo, possui algumas características bem delineadas, apontadas na definição de José Maurício Pereira Águia:

[...] Trata-se de imposto sobre consumo que incide sobre o valor agregado (ou acrescentado), das transações de bens e serviços. Alcança diretamente a livre circulação de bens e serviços, incidindo sobre todas as fases da cadeia produtiva, desde a produção ou importação até o consumo final do bem ou da utilização do serviço prestado, sendo assim um imposto plurifásico.

$[\ldots]$

Pode-se afirmar, em síntese, que o IVA é um imposto geral sobre o consumo, nãocumulativo, com base tributável alargada (bens e serviços), que não discrimina o bem importado em relação ao nacional, neutro (não interfere na cadeia produtiva), que utiliza preferencialmente o regime de tributação no destino, e que gera condições para alcançar-se a harmonização fiscal dos impostos indiretos (ÁGUIA, 2007, p. 124, 133).

Extraem-se, da definição transcrita, cinco aspectos do imposto em análise: nãocumulatividade, base tributável alargada, neutralidade, não-discriminação e tributação preferencialmente no destino. $\mathrm{O}$ autor apresenta, ainda, outras duas características, quais sejam, 
MORAIS, Maria Laura Clemente; MELLO, Elizabete Rosa de. Federalismo fiscal, autonomia financeira e cooperação federativa: um olhar sobre a possibilidade de instituição de um imposto sobre o valor agregado no Brasil a partir das consequências do "poder de não tributar"

a utilização do método do crédito do imposto ou do método das faturas, que permite ao imposto ser não-cumulativo, e a aplicação do regime do crédito financeiro no lugar do crédito físico; ambas se relacionam ao modo de cálculo do tributo. A primeira "[...] implica em deduzir-se do montante do imposto liquidado (debitado) nas transmissões de bens e serviços efetuados, o valor total de imposto suportado nas aquisições de bens e serviços, em um mesmo período de apuração" (ÁGUIA, 2007, p. 125). Quanto à segunda, na adoção do crédito financeiro, ao contrário do que ocorre no físico (aplicado ao ICMS e ao IPI), “[...] o crédito não estaria vinculado ao produto ou mercadoria, ou ainda ao serviço, mas sim ao encargo financeiro decorrente do imposto, pela aquisição de bens e serviços" (ÁGUIA, 2007, p. 127).

A base tributável alargada refere-se à possibilidade de incidência sobre bens e serviços de um modo geral, sem distinguir mercadorias e serviços, como ocorre no sistema brasileiro. Quanto a este aspecto, pode-se inferir que a adoção do imposto seria benéfica aos Municípios, uma vez que o ISSQN, conforme exposto anteriormente, tem sua incidência limitada pela lista anexa à Lei Complementar nº 116/2003, além da própria restrição constitucional relativa aos serviços compreendidos no ICMS. Ademais, os Municípios menores geralmente não possuem aptidão para uma arrecadação satisfatória do ISSQN (ÁGUIA, 2007).

A neutralidade está ligada à característica plurifásica do imposto em estudo e à nãocumulatividade. $\mathrm{O}$ tributo incide ao longo de toda a cadeia produtiva, contudo não interfere no custo das diversas operações, por permitir a dedução do IVA quando da aquisição do bem ou da contratação do serviço. Desse modo, a carga tributária é suportada apenas pelo consumidor final, sendo este o contribuinte de fato, assim como se verifica no ICMS e no IPI (ÁGUIA, 2007).

$\mathrm{O}$ aspecto da não-discriminação se refere à ausência de diferenciação entre bens e serviços em virtude de sua origem (nacional ou estrangeira). A despeito de esta característica se referir mais diretamente às relações internacionais, também se contrapõe à estrutura brasileira no que concerne à guerra fiscal, na medida em que a legislação tributária pátria permite a variação de alíquotas de acordo com o Estado-membro, ao passo que o IVA “[...] seria aplicado em toda base alargada [...], podendo-se, talvez, se for o caso, aplicar redução de imposto somente em relação a alguns serviços ou bens sociais, como os serviços de saúde, educação, etc." (ÁGUIA, 2007, p. 131-132). Sob tal perspectiva, portanto, sua adoção, além de promover a simplificação da atividade tributária, teria o condão de por fim à guerra fiscal, por meio do estabelecimento de uma alíquota nacional única e a restrição de benefícios fiscais a um número reduzido de bens e serviços. 
MORAIS, Maria Laura Clemente; MELLO, Elizabete Rosa de. Federalismo fiscal, autonomia financeira e cooperação federativa: um olhar sobre a possibilidade de instituição de um imposto sobre o valor agregado no Brasil a partir das consequências do "poder de não tributar"

A preferência pelo regime de tributação no destino, presente no IVA, é oposta à lógica atual do ICMS, que, mesmo após as alterações trazidas pela Emenda Constitucional no 87/2015, privilegia o regime de tributação na origem, o que “[...] dá ensejo à chamada guerra fiscal, consistente na política de atrativos fiscais levada a efeito por alguns Estados" (PAULSEN, 2018, p. 372). Isso, somado a outras características, como a existência de situações em que o imposto é cumulativo (artigo 155, $\S 2^{\circ}$, inciso II, da CRFB/1988) e o fato de sua base tributável ser restrita, afasta a ideia de que o ICMS já seria um modelo de IVA no Brasil.

Por unificar a tributação sobre o consumo e, portanto, alterar significativamente a distribuição de competências tributárias entre os entes da Federação, a adoção de um imposto nos moldes do IVA é considerada por alguns doutrinadores, como Piscitelli (2017) e Harada (2018), uma violação ao pacto federativo, uma vez que a autonomia financeira dos entes dependeria da preservação de seu poder de instituir tributos. Na próxima seção, pretende-se desconstruir essa lógica, a partir de uma reanálise dos mecanismos próprios do federalismo fiscal, considerando-se os problemas advindos da prática excessiva de renúncia de receitas tributárias.

\section{Federalismo fiscal: um novo olhar sobre os mecanismos de cooperação e de promoção da autonomia financeira dos entes federativos}

A autonomia de um ente federativo pressupõe, para sua efetividade, a existência de meios aptos à garantia de recursos financeiros para o custeio de suas despesas, sem que o membro dependa de transferências discricionárias por parte de outro ente. Como apontam Oliveira e Rossignoli (2019, p. 399), "De fato, não há federalismo real, baseado na lógica de igualdade entre os entes federados, em um sistema que dependa em grande parte de repasses voluntários", haja vista que, em tal cenário, a transferência não obrigatória de recursos não raramente cria uma relação de subjugação política do ente destinatário da verba perante o concessor.

A CRFB/1988 estabeleceu como instrumentos de promoção da autonomia financeira de seus entes políticos a distribuição de competências tributárias e a repartição de receitas fiscais, que traduzem o pacto federativo fiscal, na síntese de Dalmolin e Carvalho (2019, p. 41):

A estipulação das competências tributárias pela Constituição Federal assegura que os entes federados terão receitas próprias para suprir seus gastos, oriundos dos tributos 
MORAIS, Maria Laura Clemente; MELLO, Elizabete Rosa de. Federalismo fiscal, autonomia financeira e cooperação federativa: um olhar sobre a possibilidade de instituição de um imposto sobre o valor agregado no Brasil a partir das consequências do "poder de não tributar"

de sua competência. Os recursos assim arrecadados representam apenas uma parte dessas receitas próprias. O restante deriva da repartição das receitas tributárias, em que a União é obrigada, constitucionalmente, a repassar parte de sua arrecadação para estados e municípios, e os primeiros igualmente obrigados ao repasse de parte de sua arrecadação aos municípios. Essa estipulação constitucional que importa nos recursos próprios de cada ente subnacional é o conteúdo do Pacto Federativo Fiscal.

A Carta de 1988 previu, ainda, a necessidade de suporte entre os entes federativos, para o desenvolvimento conjunto em prol do Estado brasileiro, daí o enquadramento do federalismo pátrio como cooperativo. Em sua dimensão fiscal, o federalismo brasileiro tem como principal exemplo de cooperação justamente a transferência de recursos advindos da arrecadação tributária. Entretanto, este mecanismo tende a ser interpretado de forma negativa, segundo a qual haveria uma relação de dependência do ente a que se deve o repasse com relação ao ente tributante e/ou arrecadador.

Propõe-se, nesta seção, uma crítica à tradicional interpretação dos mecanismos de promoção do federalismo fiscal, pela qual a distribuição de competências tributárias ganha preeminência sobre a repartição de receitas. Tal crítica se constrói especialmente a partir da exposição dos problemas decorrentes do excesso de renúncia fiscal que o modelo atual de tributação sobre o consumo permite.

\subsection{Federalismo cooperativo e autonomia financeira dos membros da Federação}

A autonomia de um ente federativo se relaciona classicamente com sua capacidade de se auto-organizar, autogovernar e autoadministrar. Para viabilizar o efetivo exercício dessas "prerrogativas", bem como das obrigações constitucionais delas advindas, é forçoso garantir aos membros da Federação o acesso a recursos financeiros, já que "[...] A independência financeira do ente federado é condição necessária da sua autonomia política e administrativa" (BARROSO, 2009, p. 299).

Além do desafio de promover a efetiva autonomia dos entes federativos, deve-se conciliá-la com o objetivo de desenvolvimento do Estado brasileiro, o que pressupõe um apoio mútuo entre seus membros. A CRFB/1988 contemplou expressamente o federalismo cooperativo ao longo de sua redação, como, por exemplo, no parágrafo único do artigo 23, o qual dispõe que "Leis complementares fixarão normas para a cooperação entre a União e os Estados, o Distrito Federal e os Municípios, tendo em vista o equilíbrio do desenvolvimento e do bem-estar em âmbito nacional” (BRASIL, 1988). Mencionem-se, ainda, os artigos 30, incisos VI e VII (cooperação dos entes federativos nas áreas da educação e da saúde), 2016-A, $\S 1^{\circ}$, inciso IV (cooperação cultural) e 241 (cooperação por meio de consórcios e convênios, 
MORAIS, Maria Laura Clemente; MELLO, Elizabete Rosa de. Federalismo fiscal, autonomia financeira e cooperação federativa: um olhar sobre a possibilidade de instituição de um imposto sobre o valor agregado no Brasil a partir das consequências do "poder de não tributar"

para a melhor prestação de serviços públicos). Com relação ao federalismo fiscal, a cooperação entre os entes federativos ganha espaço, principalmente, com a repartição de receitas tributárias, disciplinadas entre os artigos 157 e 162 da CRFB/1988.

Uma grande dificuldade do federalismo é a harmonização entre os interesses de cada um dos entes políticos e a promoção de práticas de apoio entre eles (federalismo cooperativo). Nas palavras de Marcus Abraham:

Tema sobremaneira relevante no Direito Financeiro brasileiro e que merece destaque
é o federalismo fiscal, expressão financeira da forma com que os entes federativos -
União, Estados, Distrito Federal e Municípios - se organizam e se relacionam na
realização do seu munus, enfrentando e harmonizando as tensões decorrentes de uma
estrutura heterogênea, decorrente de uma multiplicidade de interesses e das diferenças
regionais - culturais, sociais e econômicas -, na busca da implementação de um
modelo federal cooperativo, a fim de realizar um objetivo comum para toda a nação.
Na lição de Reinhold Zippelius, o federalismo cooperativo em sentido estrito traz
consigo a ideia de uma "obrigação ao entendimento" (Verständigungszwang), ou seja,
a necessidade de que os entes federativos se harmonizem mutuamente e até mesmo
aceitem compromissos entre si (ABRAHAM, 2018, p. 43).

De fato, o pacto federativo não se limita à salvaguarda da autonomia dos entes políticos. Os membros de uma Federação, como partes de uma figura maior (o Estado), devem atuar visando não apenas ao seu desenvolvimento interno, mas também ao bem nacional. Ferraz Júnior (1998) emprega um termo ainda mais expressivo para se referir ao federalismo cooperativo, qual seja, federalismo solidário, tendo em vista que "[...] as relações interindividuais entre as entidades que compõem a federação, cujo objetivo deve ser o fomento das finalidades comuns, têm um sentido jurídico-político que as transcende" (FERRAZ JÚNIOR, 1998, p. 278).

No entanto, verifica-se no plano fático uma profunda distorção do modelo cooperativo almejado pela CRFB/1988. A distribuição das competências tributárias entre os membros da Federação, especificamente com relação à tributação sobre o consumo, abre caminho para a disputa entre os entes por atração de investimentos, cujo principal instrumento é a renúncia fiscal. Gustavo de Paiva Gadelha (2010) denuncia a vigência de um novo federalismo, de viés competitivo: 
MORAIS, Maria Laura Clemente; MELLO, Elizabete Rosa de. Federalismo fiscal, autonomia financeira e cooperação federativa: um olhar sobre a possibilidade de instituição de um imposto sobre o valor agregado no Brasil a partir das consequências do "poder de não tributar"

Muito tem se falado em "crise" da estrutura federalista, porquanto não mais seria suficiente a abarcar os interesses individuais dos entes subnacionais em compasso com o objetivo geral da nação. Dessa forma, seriam rompidos os laços cooperacionais, emergindo um "novo federalismo" impulsionado pelo capitalismo crescente. Tratase, pois, do federalismo competitivo, em que os membros da federação desprezam objetivos e planos globais (da federação) e passam a perseguir interesses próprios, em prejuízo de um outro membro ou da própria federação. [...] Os entes da federação têm tomado consciência do poder de que dispõem. Era o risco calculado da autonomia descentralização político-administrativa - donde se imaginava que a criatura (entes subnacionais) poderia rebelar-se contra o criador (Federação enquanto unidade). Com efeito, é o que se pode constatar com o incremento da guerra fiscal. Há uma deturpação da competência outorgada (no interesse do desenvolvimento da nação) para a perseguição de interesses individuais. Enfim, esse é o novel sistema federativo que vem se instaurando e que, ao contrário da essência federativa, além de não zelar pelos laços cooperacionais, sequer debate acerca do bem-estar geral, cuja vantagem individual é o único objetivo. Deixa-se de ter uma visão macro e global da federação para um ponto de vista individualista e unitário (GADELHA, 2010, p. 44-45).

A harmonização entre as duas faces do federalismo - autonomia e cooperação perpassa uma necessária reanálise de seus próprios mecanismos conexos à sua dimensão fiscal - distribuição das competências tributárias, atribuição de capacidade tributária ativa e repartição de receitas tributárias -, com a reconstrução do papel de cada um destes, diante da tradicional política de não tributar dos entes federativos, notadamente dos Estados-membros. É o que se desenvolverá nas próximas subseções.

\subsection{Federalismo fiscal além da competência tributária}

A autonomia dos entes federativos abrange sua autossuficiência financeira, ou seja, a cada ente devem ser assegurados instrumentos de obtenção de receita para o custeio de suas despesas, sem que haja uma completa ou significativa dependência com relação aos demais entes. Desse modo, o Sistema Tributário Nacional se estrutura a partir da necessidade de promoção da autonomia financeira dos Municípios, dos Estados, do Distrito Federal e da União.

Dentre os instrumentos de salvaguarda da autonomia dos entes da Federação conexos ao federalismo fiscal, destacam-se a divisão das competências tributárias, a atribuição de capacidade tributária ativa e a repartição de receitas (MELLO, 2013). A primeira define-se como “[...] a aptidão para criar tributos, mediante a edição do necessário veículo legislativo (art. 150, I, CR), indicador de todos os aspectos de sua hipótese de incidência” (COSTA, 2017, p. 70). Costuma receber maior atenção, haja vista que, em uma primeira análise, parece conferir ao ente poderes mais expressivos (e.g. instituição de tributos e alteração de suas alíquotas). Por essa razão, a discriminação das competências tributárias tende a se confundir com o próprio federalismo fiscal, o que lhe confere a falsa noção de intangibilidade, ou seja, não seria possível 
MORAIS, Maria Laura Clemente; MELLO, Elizabete Rosa de. Federalismo fiscal, autonomia financeira e cooperação federativa: um olhar sobre a possibilidade de instituição de um imposto sobre o valor agregado no Brasil a partir das consequências do "poder de não tributar"

uma profunda alteração em sua distribuição, sob o risco de se violar a autonomia dos entes federativos em si.

Não obstante, observa-se que a manutenção das competências tributárias tais como estabelecidas atualmente no texto constitucional tem ocasionado uma ineficiência geral do sistema tributário, contribuindo para uma arrecadação deficiente. Esse cenário se observa especialmente na tributação sobre o consumo, tendo está sido fragmentada em diversos tributos, cujas competências foram distribuídas entre a União (IPI, PIS, COFINS), os Estados-membros (ICMS) e os Municípios (ISSQN). Não se nega que a divisão da competência para a instituição de impostos em geral (e não apenas aqueles ligados à atividade consumerista) não foi realizada de forma randômica. De fato, o constituinte estabeleceu as competências de modo criterioso, por meio, por exemplo, da proximidade do ente político com a verificação do fato gerador (como no caso do IPTU para os Municípios) e da importância regulatória do tributo (e.g. impostos aduaneiros para a União).

Ainda assim, a pluralidade de tributos implica uma maior complexidade fiscal, em virtude do consequente estabelecimento de um número significativo de obrigações tributárias, principais e acessórias, o que tende a influir de modo negativo no resultado da arrecadação. Ademais, o poder de cada Estado-membro de controlar as alíquotas do ICMS e de conceder benefícios cria um espaço para guerras fiscais, o que não foi neutralizado por completo com o advento da Emenda Constitucional $n^{\circ} 87 / 2015$ e com as disposições originais que limitam a discricionariedade dos Estados-membros acerca do imposto (artigo 155, $\S 2^{\circ}$, incisos IV ao VI e XII, alínea $g$ ).

Em resumo, pretende-se esclarecer que o tratamento usualmente dispensado às competências tributárias como se fossem praticamente "intocáveis" é fruto de uma noção incompleta do federalismo fiscal, segundo a qual este se resumiria à divisão daquelas, e tem como consequências, principalmente: a) a subestimação de outros mecanismos de promoção do federalismo fiscal, tais como a atribuição de capacidade tributária ativa e a repartição de receitas e b) a hesitação em reformar substancialmente o sistema tributário, com fins não apenas à sua simplificação, mas também à otimização dos resultados da arrecadação, por meio da instituição de um imposto único sobre o consumo em substituição a tributos como o IPI, ICMS, ISSQN, PIS e COFINS.

O poder de tributar do Estado não se limita à instituição de tributos, ao controle de suas alíquotas e à fixação da base de cálculo. Não se resume, portanto, à competência tributária, pois também se refere ao expediente da cobrança e da arrecadação do tributo, ou seja, à capacidade tributária ativa (MELLO, 2013). A própria redação do texto constitucional atesta tal 
MORAIS, Maria Laura Clemente; MELLO, Elizabete Rosa de. Federalismo fiscal, autonomia financeira e cooperação federativa: um olhar sobre a possibilidade de instituição de um imposto sobre o valor agregado no Brasil a partir das consequências do "poder de não tributar"

abrangência, uma vez que, na Seção II do Título IV, que trata das limitações ao poder de tributar, são estabelecidas restrições não somente com relação à instituição e ao aumento de impostos, mas também a respeito de sua exigência ou cobrança (artigo 150).

A capacidade tributária ativa, consistente na "[...] aptidão para arrecadar e fiscalizar a arrecadação de tributos" (COSTA, 2017, p. 175), tem sua importância concentrada especialmente em sua relação com a eficiência da atividade fiscal. Uma atuação eficiente do Fisco pressupõe o conhecimento de dados a respeito do contribuinte ou responsável tributário, cuja obtenção costuma ser facilitada pela maior proximidade do ente federativo ou outra entidade com o sujeito passivo. Por essa razão, é desejável a comunicação entre as bases de dados dos entes tributantes, o que encontra previsão expressa no Código Tributário Nacional (CTN), em seu artigo 199. Além do compartilhamento de informações, outra forma de facilitação da atividade fiscalizadora e arrecadatória é a delegação da capacidade tributária ativa (artigo $7^{\circ}$ do CTN). Esta pode ser compreendida como elemento caro ao federalismo fiscal em especial por sua relevância no que concerne à cooperação entre os entes, quando há sua delegação ou troca de informações.

Além disso, em determinados casos, pode influir diretamente na autonomia financeira dos entes federativos, como na situação prescrita no artigo 153, $§ 4^{\circ}$, inciso III, da CRFB/1988. O Município, optando por fiscalizar e cobrar o imposto sobre a propriedade territorial rural (ITR), fará jus a todo o produto da arrecadação. Não é conferida competência tributária (é defesa a redução do imposto ou qualquer outra forma de renúncia fiscal); contudo, a capacidade tributária ativa - que não é delegada, mas sim atribuída constitucionalmente - nesse caso oferece uma fonte de receita ao Município, inclusive prescindível do repasse pela União.

Deve-se mencionar, ainda, a repartição de receitas tributárias como instrumento constitucional do federalismo fiscal. Esta, em essência, insere-se no campo de estudo do Direito Financeiro e não do Direito Tributário, na medida em que não guarda relação com o contribuinte. Trata-se de uma questão pertinente apenas aos entes tributantes (HARADA, 2018). Não obstante, é cara à presente discussão, uma vez que "O Federalismo Fiscal não se atém somente ao poder de tributar, mas também ao poder de disciplinar sobre a repartição de receitas tributárias" (MELLO, 2013, p. 27).

Conforme sua origem, as receitas públicas classificam-se como originárias, derivadas e transferidas, estas podendo ser divididas em voluntárias e obrigatórias. Ao presente estudo, interessam especificamente as receitas transferidas obrigatórias, uma vez que nelas se enquadra a repartição de receitas tributárias estabelecida pela CRFB/1988, entre os artigos 157 e 162, correspondendo à transferência de recursos de um ente federativo a outro. "Portanto, 
MORAIS, Maria Laura Clemente; MELLO, Elizabete Rosa de. Federalismo fiscal, autonomia financeira e cooperação federativa: um olhar sobre a possibilidade de instituição de um imposto sobre o valor agregado no Brasil a partir das consequências do "poder de não tributar"

diferentemente do que ocorre com as receitas originárias e derivadas, esses recursos decorrem não de uma relação que se estabelece entre Estado e particulares, mas sim em virtude de relações entre os entes da Federação" (PISCITELLI, 2018, p. 97). A repartição de receitas compõe, ao lado da competência tributária e da capacidade tributária ativa, o conjunto de mecanismos do federalismo fiscal pátrio, dentre os quais se destaca como aquele que mais se aproxima do federalismo cooperativo. Isso porque corresponde a uma transferência de parcela do produto arrecadado por um ente a outro, ou seja, pressupõe uma operação que enseja um necessário vínculo entre os membros da Federação. A cooperação, apesar de também ser observada com relação à competência tributária (e.g. convênios sobre o ICMS) e à capacidade tributária ativa (e.g. permuta de informações e delegação), o é de modo incidental, pois não se encontra na própria definição de competência tributária ou de capacidade tributária ativa, sendo então uma característica periférica destas.

No entanto, sob a perspectiva da autonomia dos entes federativos, parte da doutrina entende que a repartição de receitas tributárias seria um instrumento inferior à distribuição de competências, em razão justamente da suposta relação de dependência do ente que recebe a transferência perante o ente que a realiza. O poder de tributar promoveria uma maior autonomia financeira dos membros da Federação uma vez que, desse modo, estes teriam o controle do próprio tributo, podendo decidir a respeito de sua instituição, base de cálculo e alíquotas. Ademais, como, em regra, o ente que possui a competência tributária também detém a capacidade tributária ativa, sob seu encargo estariam ainda as funções de fiscalização, cobrança e arrecadação. Outra parcela dos juristas, contudo, possui posicionamento diverso, no sentido de que “[...] a autonomia financeira dos entes federados não precisa ser atingida necessariamente pela garantia do exercício de competências tributárias próprias, sendo possível atingir tal condição por meio de participação nas transferências e repartições das rendas tributárias" (OLIVEIRA, G. da G. V. de, 2016 p. 128-129).

A primeira linha de pensamento (que privilegia a distribuição de competências sobre a repartição de receitas tributárias) leva, por vezes, à conclusão de que a instituição de um imposto único comprometeria significativamente a autonomia financeira dos entes, como no entendimento de Kiyoshi Harada: 
MORAIS, Maria Laura Clemente; MELLO, Elizabete Rosa de. Federalismo fiscal, autonomia financeira e cooperação federativa: um olhar sobre a possibilidade de instituição de um imposto sobre o valor agregado no Brasil a partir das consequências do "poder de não tributar"

À primeira vista, pode parecer que o mecanismo de participação no produto de arrecadação de imposto alheio favorece as entidades políticas participantes, à medida que as livra dos custos de implantação, de fiscalização e de arrecadação. Na realidade, porém, tolhem as autonomias dessas entidades, porque inúmeros entraves burocráticos, inclusive os de natureza política, se interpõem, dificultando o recebimento oportuno dessas participações, sem contar as limitações e condicionamentos previstos na própria Carta Política e na legislação infraconstitucional, impondo o direcionamento dos recursos que lhes são transferidos. A única forma de assegurar a independência político-administrativa às entidades componentes da Federação é conferir-lhes a autonomia financeira, por meio de tributos próprios, o que importa na reformulação da discriminação constitucional de rendas, e que torna cada vez mais difícil qualquer ideia de implantação do chamado imposto único (HARADA, 2018, p. 55).

Do posicionamento crítico do autor, extrai-se a legítima preocupação quanto à forma de efetivação do repasse e as condicionantes que recaem sobre ele. No que concerne a eventuais entraves de natureza política, acredita-se que possam recair sobre as receitas transferidas voluntárias, sendo significativamente minimizados com relação às receitas transferidas obrigatórias, uma vez que estas possuem respaldo constitucional ${ }^{3}$. Não obstante, é plausível e necessária - a reflexão a respeito das hipóteses de condicionamento do repasse previstas no parágrafo único do artigo 160 da CRFB/1988, com a redação conferida pela Emenda Constitucional $n^{\circ}$ 29/2000.

Há duas circunstâncias nas quais a União e os Estados-membros podem, legitimamente, reter os recursos que devem transferir. O inciso II do parágrafo único do artigo 160 se refere à situação em que o ente a ser favorecido pelo repasse (Estado-membro, Distrito Federal ou Município) não aplica em ações e serviços públicos de saúde recursos mínimos provenientes dos valores da arrecadação de impostos de sua competência e das transferências de receitas ou retenções na fonte previstas nos artigos 157 e 159 da CRFB/1988. A finalidade da norma é clara: compelir os entes a realizar investimentos na saúde. A despeito dessa nobre justificativa, a disposição constitucional deixa, por óbvia impossibilidade, de aplicar medida semelhante à União, a qual também possui responsabilidade perante o sistema de saúde, devendo igualmente efetuar investimentos nesse setor. Conclui-se, dessa forma, que a União não sofrerá sanções de natureza financeira em caso de descumprimento do disposto no artigo $198, \S 2^{\circ}$, inciso I, da CRFB/1988, ao passo que os demais entes estão sujeitos à retenção dos valores que a eles pertencem pela repartição de receitas tributárias.

O inciso I apresenta hipótese ainda mais gravosa. A União ou os Estados-membros podem reter os recursos a serem transferidos caso o ente "beneficiado" possua débito consigo ou com suas autarquias. Em sua redação original, o parágrafo único do artigo 160 conferia tão

\footnotetext{
${ }^{3}$ Com relação às transferências obrigatórias indiretas, também pode haver influência de decisões eminentemente políticas, o que, apesar de inevitável, é amenizado pela obrigatoriedade de a distribuição dos recursos destinados aos fundos de participação dos Estados-membros, Distrito Federal e Municípios se orientar pela finalidade de equilíbrio socioeconômico entre os entes da Federação (artigo 161, inciso II, CRFB/1988).
} 
MORAIS, Maria Laura Clemente; MELLO, Elizabete Rosa de. Federalismo fiscal, autonomia financeira e cooperação federativa: um olhar sobre a possibilidade de instituição de um imposto sobre o valor agregado no Brasil a partir das consequências do "poder de não tributar"

somente à União a prerrogativa da retenção, não havendo, ainda, previsão quanto a dívidas perante autarquias. A norma então já era alvo de críticas na doutrina, “[...] pois admitir que a União possa condicionar a entrega de recursos decorrentes da repartição de receitas tributárias aos entes menores ao pagamento de seus créditos pode comprometer a autonomia financeira de Estados e Municípios [...]” (OLIVEIRA, G. da G. V. de, 2016, p. 35). Com a ampliação das hipóteses de retenção, essa questão se intensificou ${ }^{4}$.

As possibilidades de condicionamento do repasse de recursos devem, destarte, receber uma interpretação restritiva. Luís Roberto Barroso (2009), quando procurador do Estado do Rio de Janeiro, editou o Parecer $n^{\circ}$ 01/2009, endereçado à então Procuradora-Geral do Estado, a respeito do sentido e alcance do artigo 160, parágrafo único, da CRFB/1988. Embora com enfoque na relação entre União e Estados-membros, a linha interpretativa então defendida pode ser aplicada também às relações entre União e Municípios, União e Distrito Federal e Estadosmembros e Municípios. Com a afirmação do caráter excepcional da retenção de recursos, estabelecem-se alguns parâmetros a guiarem a aplicação da norma constitucional.

Inicialmente, enfatiza-se que os créditos aptos a justificar o condicionamento do repasse devem ser de titularidade direta da União e de suas autarquias (incluem-se aqui também os Estados-membros, o Distrito Federal e suas autarquias). Portanto, não estão contempladas as empresas públicas, sociedades de economia mista e fundações públicas. É defesa, ainda, a utilização de mecanismos de fraude, como, por exemplo, a cessão de crédito de uma dessas pessoas jurídicas àquelas cujos créditos podem de fato ensejar a retenção. Ademais, apesar de o condicionamento do repasse parecer uma faculdade do ente credor, devem ser observados critérios objetivos para a decisão quanto à aplicação ou não da norma constitucional. $\mathrm{O}$ primeiro desses critérios é a inviabilidade de retenção quando pendente disputa administrativa ou judicial sobre o crédito, em respeito ao princípio do devido processo legal. O segundo parâmetro corresponde ao dever de observância dos princípios orçamentários, notadamente os da legalidade e da anualidade. Tal exigência se cumpre com a comunicação até $1^{\circ}$ de julho ao ente devedor a respeito dos valores a serem retidos. Por fim, o condicionamento do repasse não deve ocasionar a inviabilização do cumprimento das obrigações constitucionais essenciais do ente destinatário da transferência, tais como os investimentos mínimos em educação e saúde, os repasses obrigatórios aos demais Poderes e o pagamento precatórios referentes a verbas de natureza alimentar (BARROSO, 2009).

\footnotetext{
${ }^{4}$ Parte da doutrina entende serem inconstitucionais as ECs n ${ }^{\circ}$ 3/1993 e n ${ }^{\circ}$ 29/2000. Isso porque as alterações por elas introduzidas no artigo 160 , parágrafo único, ao ampliarem a possibilidade de retenção de recursos, violariam o federalismo como cláusula pétrea (artigo 60, $§ 4^{\circ}$, inciso I, CRFB), (OLIVEIRA, G. da G. V. de, 2016).
} 
MORAIS, Maria Laura Clemente; MELLO, Elizabete Rosa de. Federalismo fiscal, autonomia financeira e cooperação federativa: um olhar sobre a possibilidade de instituição de um imposto sobre o valor agregado no Brasil a partir das consequências do "poder de não tributar"

Percebe-se, dessa forma, que a promoção da autonomia financeira dos entes federativos por meio da repartição de receitas tem como principal desafio a garantia do repasse, razão pela qual o artigo 160, parágrafo único, da CRFB/1988, suscita um problema relevante. Eventual criação de um imposto único sobre o consumo, em substituição a tributos como o IPI, ICMS, ISSQN, PIS e COFINS, exigiria uma revisão da referida norma. Isso porque, ao se ampliar a importância da repartição de receitas em detrimento da distribuição de competências tributárias, deve-se assegurar a transferência de modo mais efetivo e com menos óbices.

Outro dispositivo constitucional que igualmente merece revisão, na eventualidade de instituição de um IVA, é o $§ 4^{\circ}$ do artigo 167 (incluído pela Emenda Constitucional nº 3/1993), por meio do qual foi introduzido "O poder da União em reter receitas provenientes de impostos de Estados e Municípios" (LIZIERO, ALCÂNTARA, 2020, p. 348). Nesse caso, percebe-se um poderio ainda maior do ente nacional, haja vista que a este é permitida ingerência sobre recursos provenientes de impostos municipais e estaduais, com a possibilidade de sua retenção como garantia de dívida do ente subnacional. A prévia anuência do Estado, Distrito Federal ou Município, por meio de celebração de contrato de confissão e refinanciamento de dívida, não faz desaparecer a gravidade representada pela norma constitucional, pois, por vezes, a concessão da garantia não é uma escolha de fato do agente político à frente do ente federativo, mas sim sua única opção (LIZIERO, ALCÂNTARA, 2020).

Não obstante, tais preocupações não inviabilizam as reflexões sobre um IVA para o Brasil, o qual, em verdade, desde que acompanhado da revisão dos artigos mencionados, pode ensejar o fortalecimento do federalismo fiscal, em vista do uso distorcido da competência tributária, com renúncias fiscais desmedidas, que têm contribuído em alguma medida para o superendividamento dos entes e, ainda, ocasionado o desrespeito ao destinatário final dos recursos financeiros arrecadados. Como apontam Marón e Tavares (2017, p. 460-461):

\footnotetext{
O desenho federativo, por sua dinâmica que impossibilita a ideia estanque de um artifício de autonomia entre entes políticos descentralizados, requer, ao contrário da oposição centralização/descentralização, a elaboração de um mecanismo de coordenação, especialmente no que tange a sua feição fiscal, da qual participe a União e as demais unidades da Federação, a fim de que sejam enfrentadas as diferenças regionais, a competição vertical e, ainda, o endividamento das unidades autônomas.
}

De fato, uma eventual reforma do Sistema Tributário Nacional, notadamente da tributação sobre o consumo, deve privilegiar o aprimoramento da cooperação entre os entes federativos, incorporando, por exemplo, mecanismos de exercício da capacidade tributária ativa (atividades de fiscalização, cobrança e arrecadação) de forma compartilhada, ramificada e coordenada. 
MORAIS, Maria Laura Clemente; MELLO, Elizabete Rosa de. Federalismo fiscal, autonomia financeira e cooperação federativa: um olhar sobre a possibilidade de instituição de um imposto sobre o valor agregado no Brasil a partir das consequências do "poder de não tributar"

Na próxima subseção, será tratado com mais detalhes o tema da renúncia fiscal, com o objetivo de se evidenciar que a atual configuração da distribuição de competências tributárias assegura uma autonomia tão somente formal aos membros da Federação.

\subsection{0 "poder de não tributar" e renúncia fiscal: $A$ "farsa" da autonomia dos entes federativos}

Como visto, o poder de tributar engloba a competência tributária e a capacidade tributária ativa, ou seja, corresponde às atribuições de instituir o tributo, determinar seus aspectos específicos (alíquotas e base de cálculo, por exemplo), fiscalizar o sujeito passivo, cobrar o cumprimento das obrigações tributárias e arrecadar o valor do crédito. Em geral ${ }^{5}$, o poder de tributar é acompanhado do "poder de não tributar”, termo utilizado por Barbosa (2012) para se referir à possibilidade de renúncia fiscal por meio da concessão de benefícios fiscais, notadamente as isenções.

A Lei Complementar no 101/2000 (Lei de Responsabilidade Fiscal) estabelece, em seu artigo 14, as condições para a concessão de benefícios e incentivos fiscais, ou seja, para a renúncia de receita tributária. A norma vincula todos os entes federativos, conforme dispõe seu artigo $1^{\circ}, \S 2^{\circ}$. Logo, a União, os Estados-membros, o Distrito Federal e os Municípios devem observar as exigências para a renúncia fiscal. Excepcionam-se tão somente os benefícios e incentivos fiscais referentes aos impostos de importação (II), de exportação (IE), de produtos industrializados (IPI) e de operações de crédito, câmbio e seguro, ou relativas a títulos ou valores mobiliários (IOF), todos de competência da União, justamente em virtude de seu caráter eminentemente regulatório. $\mathrm{O}$ ente deve se atentar ao impacto orçamentário da renúncia de receita tributária, sendo forçoso demonstrar que as metas fiscais não serão comprometidas (artigo 14, caput e inciso I), ou, caso contrário, adotar medidas de compensação (artigo 14, caput e inciso II).

Dentre as formas de renúncia fiscal apontadas no $\S 1^{\circ}$ do artigo 14 da LRF, destaca-se a isenção, por ser o instrumento de concessão de benefícios e incentivos fiscais utilizado de modo mais recorrente pelos entes federativos. É classificada pelo CTN (artigo 175, inciso I) como modalidade de exclusão do crédito tributário. Entretanto, “[...] a doutrina mais moderna a vem entendendo como norma impeditiva do exercício da competência tributária em certas situações, em razão da mutilação de um ou de alguns aspectos da hipótese de incidência"

\footnotetext{
${ }^{5} \mathrm{O}$ poder de não tributar nem sempre é integral, encontrando restrições legais. Como exemplo, pode-se mencionar a limitação de concessão de benefícios e incentivos fiscais quanto ao ISSQN, expressa no artigo $8^{\circ}-\mathrm{A}, \S 1^{\circ}$, da Lei Complementar $\mathrm{n}^{\circ}$ 116/2003, incluído pela Lei Complementar $\mathrm{n}^{\circ}$ 157/2016: "O imposto não será objeto de concessão de isenções, incentivos ou benefícios tributários ou financeiros, inclusive de redução de base de cálculo ou de crédito presumido ou outorgado, ou sob qualquer outra forma que resulte, direta ou indiretamente, em carga tributária menor que a decorrente da aplicação da alíquota mínima estabelecida no caput, exceto para os serviços a que se referem os subitens 7.02, 7.05 e 16.01 da lista anexa a esta Lei Complementar" (BRASIL, 2016).
} 
MORAIS, Maria Laura Clemente; MELLO, Elizabete Rosa de. Federalismo fiscal, autonomia financeira e cooperação federativa: um olhar sobre a possibilidade de instituição de um imposto sobre o valor agregado no Brasil a partir das consequências do "poder de não tributar"

(COSTA, 2017, p. 303). Essa definição conecta a isenção diretamente ao mencionado poder de "não" tributar. É uma noção interessante, na medida em que leva à conclusão de que a competência tributária pode se autorrestringir. Isso porque a concessão de uma isenção relativa a determinado tributo pressupõe que o ente que a cria tenha a competência sobre o mesmo tributo. Logo, o ente, ao exercitar sua competência tributária para estabelecer uma isenção, cria uma "norma impeditiva" da mesma competência de que se valeu para conceder o benefício.

A renúncia de receita tributária se destina ao alcance de objetivos diversos da arrecadação. Os tributos assumem uma função extrafiscal, com o fim de atender ao interesse público em matéria econômica, social ou cultural. A extrafiscalidade lato sensu se observa nas normas com finalidade diversa da mera obtenção de recursos para o Estado. Nesse sentido, pode se referir inclusive a dispositivos normativos não inseridos no regime tributário (SCHOUERI, 2005). Em uma acepção mais restritiva, a função extrafiscal se faz presente quando do "[...] emprego deliberado do instrumento tributário para finalidades não financeiras, mas regulatórias de comportamentos sociais, em matéria econômica, social e política” (ATALIBA, 1968, p. 151). Consiste, destarte, em uma forma de ingerência do Estado em determinados hábitos e condutas do contribuinte, por meio da sugestão à escolha de dada opção favorável ao interesse público. A intervenção estatal no comportamento dos particulares se dá, na extrafiscalidade em sentido estrito, por indução, ou seja, a partir de medidas de incentivo ou desestímulo a determinada conduta, permanecendo uma margem de escolha para o particular (SCHOUERI, 2005).

Os benefícios fiscais de ordem econômica em geral possuem a finalidade de atrair investimentos do mercado para determinada área. Esse objetivo tem levado os Municípios e os Estados-membros a práticas avessas ao federalismo cooperativo e, em última análise, a sua própria autonomia financeira. Com relação ao primeiro (federalismo cooperativo), sua incompatibilidade com o excesso de renúncias fiscais é notória, haja vista serem estas o principal instrumento da guerra fiscal. Ademais, verifica-se que a renúncia de receitas tributárias promove, por vezes, um desrespeito com o ente ao qual cabe receber parcela do produto da arrecadação de acordo com as normas de repartição de receitas tributárias ${ }^{6}$.

No que diz respeito à autonomia financeira, o presente estudo questiona, no âmbito da tributação sobre o consumo, a posição da distribuição de competências tributárias como a forma mais genuína de garantia da existência de recursos para que os entes sejam de fato autônomos.

\footnotetext{
${ }^{6} \mathrm{O}$ tema foi alvo de questionamento perante o Supremo Tribunal Federal (Recurso Extraordinário n ${ }^{\circ} 705.423 /$ SE), especificamente quanto à concessão pela União de benefícios e incentivos fiscais para o IR e o IPI, com impacto no repasse para o Fundo de Participação dos Municípios (FPM). Na ocasião, no entanto, a Suprema Corte pátria entendeu que "Não se haure da autonomia financeira dos Municípios direito subjetivo de índole constitucional com aptidão para infirmar o livre exercício da competência tributária da União, inclusive em relação aos incentivos e renúncias fiscais, desde que observados os parâmetros de controle constitucionais, legislativos e jurisprudenciais atinentes à desoneração" (BRASIL, 2016).
} 
MORAIS, Maria Laura Clemente; MELLO, Elizabete Rosa de. Federalismo fiscal, autonomia financeira e cooperação federativa: um olhar sobre a possibilidade de instituição de um imposto sobre o valor agregado no Brasil a partir das consequências do "poder de não tributar"

Ora, se a competência tributária permite sua própria "mutilação" (COSTA, 2017) de modo significativo (renúncia fiscal em demasia), o ente federativo, apesar de ter para si o poder de tributar, possui também o tentador poder de "não" tributar, por meio do qual é capaz de renunciar a parcela do potencial de arrecadação em nome de um interesse extrafiscal que, por vezes, não é satisfeito. Alguns dos resultados são o agravamento de sua situação financeira e o aumento de sua dependência com relação aos repasses de outros membros da Federação. Em virtude desse cenário, entende-se haver, no que concerne à distribuição de competências, uma "falácia" (ou "farsa") da autonomia dos entes federativos?

Pode-se então suscitar que o disposto no artigo 14 da Lei de Responsabilidade Fiscal já inibiria o excesso de renúncia de receitas tributárias, tendo em vista que a mencionada norma impõe que o benefício ou incentivo fiscal não tenha impacto sobre as metas de resultados fiscais ou que se estabeleçam medidas de compensação. De fato, a lei assim exige. Não obstante, a situação concreta dos entes, notadamente dos Estados-membros, denuncia que, ainda que cumpridas formalmente as exigências legais (demonstração apriorística de que não haverá impacto ou de que este será neutralizado), o resultado é adverso. É o que indica, por exemplo, estudo realizado em 2014 pelo Banco Interamericano de Desenvolvimento (BID), em que se verificou que a renúncia tributária em 16 (dezesseis) Estados-membros e no Distrito Federal, referente ao ICMS, correspondeu a aproximadamente o dobro dos investimentos por eles realizados no ano financeiro de 2012 (AFONSO, 2014).

Os entes federativos, em especial os Estados-membros, tornaram-se vítimas de sua lógica egoística, avessa ao crescimento igualitário das regiões do país e, portanto, contrária ao federalismo cooperativo instituído pela CRFB/1988.

Percebe-se, desse modo, que a tradicional sobreposição da distribuição de competências tributárias à repartição de receitas na escala de efetivação da autonomia financeira dos entes deve ser revista. A despeito de a primeira, em uma análise inicial, conferir maiores poderes a cada membro da Federação, observa-se na realidade que pouco tem atingido sua finalidade primordial (assegurar que os entes possuam recursos para serem de fato autônomos). Em verdade, sua configuração atual, no que concerne à tributação sobre o consumo, tem possibilitado profundas distorções no sistema cooperativo.

Diante dessas circunstâncias, não parece se sustentar o argumento de que a adoção de um imposto único sobre o consumo, por reduzir a competência tributária dos entes federativos e ampliar a importância da repartição de receitas tributárias, reduziria também sua autonomia.

7 O emprego do adjetivo "falácia" em referência à autonomia financeira dos entes federativos se encontra também em obra de J. J. de M. Oliveira (2016), contudo, para enfatizar aspecto diverso, qual seja, a concentração de boa parte do potencial de arrecadação na competência da União (OLIVEIRA, J. J. de M., 2016). 
MORAIS, Maria Laura Clemente; MELLO, Elizabete Rosa de. Federalismo fiscal, autonomia financeira e cooperação federativa: um olhar sobre a possibilidade de instituição de um imposto sobre o valor agregado no Brasil a partir das consequências do "poder de não tributar"

A preocupação com uma eventual acentuação da concentração de competências tributárias, considerando que a União já detém atualmente parcela significativa do poder de tributar herança da origem centrífuga do federalismo pátrio ${ }^{8}$ (OLIVEIRA, ROSSIGNOLI, 2019) -, é válida e deve se manter presente nos debates sobre propostas de reforma do Sistema Tributário Nacional. Contudo, não pode ser encarada como óbice insuperável à instituição de um IVA.

A uma, porque o fato de fatia considerável do potencial de arrecadação se encontrar nas mãos da União é consequência do modelo tributário brasileiro como um todo e não especificamente da tributação sobre o consumo. Em verdade, a concentração do maior potencial arrecadatório na competência da União é devida, em boa parte, aos tributos incidentes sobre manifestações de riqueza por excelência, seja pela alta carga tributária dos tributos federais, seja pelas alíquotas demasiadamente pequenas dos impostos sobre o patrimônio de competência dos demais entes federativos (sobre transmissão causa mortis ou doação, no caso dos Estados, e sobre transmissão de bens imóveis inter vivos, quanto aos Municípios). Logo, a distribuição de competências tributárias na tributação sobre o consumo, em si, não garante a autonomia financeira dos entes federativos, seja pelas já expostas distorções da finalidade do poder de "não" tributar (com a renúncia fiscal desmedida), seja pelas discrepâncias na fixação das alíquotas dos tributos sobre renda e patrimônio.

A duas, porque é possível amenizar significativamente o poderio da União com relação ao IVA por meio do compartilhamento da capacidade tributária ativa, que, como visto, também integra o poder de tributar. Um sistema ramificado, que permita que as atividades de fiscalização, cobrança e arrecadação sejam exercidas pelos entes federativos de forma colaborativa, tornaria efetivo o federalismo cooperativo em sua dimensão fiscal e conservaria parcela importante do poder de tributar dos entes subnacionais.

Destarte, acredita-se ser viável um IVA brasileiro que se adeque ao federalismo fiscal pátrio e, ainda, venha a fortalecê-lo, a depender de seu desenho. Para tal, far-se-ia necessário, conforme já aludido, rever o disposto no artigo 160, parágrafo único, da CRFB/1988, a fim de se garantir de modo mais enfático o repasse dos recursos, além de implementar um sistema de arrecadação do imposto único que privilegie uma ação conjunta dos entes, não se concentrando apenas na União.

Com a adoção de um IVA, a guerra fiscal na tributação sobre o consumo teria extintos seus principais mecanismos, quais sejam, a possibilidade de renúncia fiscal em demasia e o

\footnotetext{
${ }^{8}$ Segundo Oliveira e Rossignoli (2019, p. 398): "No Brasil, como se vê, o federalismo formou-se do centro (União centralizadora) para os cantos, abdicando o ente centralizador de suas competências. Em razão dessa fuga do centro, é conhecido como federalismo centrífugo". Nas palavras dos autores, ainda: "A tendência dos chamados federalismos centrífugos, como o nosso, é a preservação da maior parte das competências nas mãos da União, algo que, em certa medida, pode jogar por terra o próprio federalismo, existente apenas em aspectos formais" (OLIVEIRA, ROSSIGNOLI, 2019, p. 421).
} 
MORAIS, Maria Laura Clemente; MELLO, Elizabete Rosa de. Federalismo fiscal, autonomia financeira e cooperação federativa: um olhar sobre a possibilidade de instituição de um imposto sobre o valor agregado no Brasil a partir das consequências do "poder de não tributar"

regime de tributação na origem. Quanto ao primeiro, vale destacar o que se afirma a respeito na justificativa da Emenda Substitutiva Global nº 7/2018 à Proposta de Emenda à Constituição no 293-A/2004, que propunha a instituição do imposto sobre bens e serviços (IBS):

[...] a vedação a benefícios fiscais busca evitar o risco de que setores específicos busquem um tratamento diferenciado no âmbito do IBS, o que inevitavelmente leva a distorções competitivas e alocativas. A adoção de um regime uniforme de tributação para todos os bens e serviços favorece a discussão democrática entre os consumidores/eleitores e o governo, pois torna absolutamente transparente o custo de financiamento das ações do poder público.

$[\ldots]$

Ao extinguir-se a possibilidade de qualquer concessão de benefícios fiscais no âmbito do IBS, extingue-se também a guerra fiscal do ICMS e do ISS. [...]

[...] excetua[-se] da vedação à concessão de isenções e benefícios fiscais a criação de um mecanismo voltado a devolver aos consumidores de baixa renda, através de instrumentos de transferência de renda, parcela do IBS pago em suas aquisições de bens e serviços. Na medida em que se propõe a adoção de uma alíquota uniforme para todos os bens e serviços, esse dispositivo visa melhorar o impacto distributivo da tributação do consumo, através de um mecanismo muito mais eficiente que a desoneração da cesta básica (BRASIL, 2018, p. 705-716).

Percebe-se que nesta proposta havia uma tendência a por fim à extrafiscalidade na tributação sobre o consumo, ressalvando-se a possibilidade de concessão de benefícios a consumidores de baixa renda, por meio de mecanismos de transferência de renda. A função extrafiscal subsistiria no imposto seletivo, de caráter monofásico, o qual incidiria “[...] sobre bens e serviços geradores de externalidades negativas, cujo consumo se deseja desestimular, como cigarros e bebidas alcoólicas" (BRASIL, 2018, p. 703). A proposição previa, ademais, a transição gradativa para o regime de tributação no destino, respeitando, desse modo, o perfil tradicional de um IVA. Na justificativa, era ressaltado que o modelo de tributação na origem “[...] estimulou a guerra fiscal entre estados e municípios - afetando o equilíbrio da estrutura federativa brasileira -, além de gerar um viés anti-exportação no sistema tributário do país" (BRASIL, 2018, p. 701).

Quanto ao superendividamento dos entes, não é possível concluir, a priori, que a instituição de um IVA promoveria uma solução efetiva à questão, que é de cunho eminentemente orçamentário, mas que possui raízes em normas de Direito Tributário. Deve-se, no entanto, admitir que um novo sistema que vede a concessão excessiva de benefícios fiscais atingiria diretamente a prática de renúncia de receitas tributárias, ora apontada como uma das causas do agravamento do quadro financeiro dos membros da Federação. Desse modo, a criação de um IVA, longe de por fim ao superendividamento dos entes federativos, ao menos se mostra como medida apta a contribuir para tal objetivo. 
MORAIS, Maria Laura Clemente; MELLO, Elizabete Rosa de. Federalismo fiscal, autonomia financeira e cooperação federativa: um olhar sobre a possibilidade de instituição de um imposto sobre o valor agregado no Brasil a partir das consequências do "poder de não tributar"

\section{Conclusão}

A tributação sobre o consumo no Brasil abrange um número significativo de tributos, cuja competência está distribuída entre os entes federativos. A complexidade advinda desta estrutura é apontada como um fator que reduz a potencialidade da arrecadação. Além disso, a guerra fiscal e o superendividamento dos Estados-membros podem ser relacionados (aquela de modo direto, e este, em certa medida) com a forma como dispôs a CRFB/1988 acerca da competência tributária, a qual, a despeito de possuir inegável importância para a garantia da autonomia financeira dos entes federativos, tem sofrido distorções em sua finalidade, por meio da excessiva utilização da renúncia fiscal como forma de atrair investimentos.

Propostas que objetivem alterar profundamente a tributação sobre o consumo e que, para tal, sugiram alterações na distribuição de competências, não devem encontrar no federalismo fiscal uma barreira intransponível. A instituição de um imposto com as características de um IVA não viola, por si só, a salvaguarda da autonomia financeira dos membros da Federação. Ao contrário, a depender do desenho conferido ao tributo (e.g. capacidade tributária ativa compartilhada entre os entes e alteração dos artigos 160, parágrafo único, e $167, \S 4^{\circ}$, da CRFB/1988), pode contribuir para uma arrecadação otimizada e cooperativa, em comparação ao atual modelo, no qual o uso desmedido do poder de "não" tributar ocasiona uma autonomia apenas aparente dos entes federativos. Além disso, não se trata de um imposto único puro, mas sim de um imposto único sobre o consumo, mantendo-se, portanto, a competência dos entes sobre os demais tributos, relacionados às manifestações de riqueza por excelência.

O fim da guerra fiscal, ao menos com relação à atividade tributária incidente sobre o consumo, pode ser apontado como um dos prováveis impactos da eventual adoção de um imposto único com o perfil de um IVA. Isso seria possível graças a uma restrição severa à concessão de benefícios fiscais, o que poderia contribuir, ainda, para a recuperação financeira dos entes federativos, em especial dos Estados-membros, uma vez que as renúncias fiscais têm sido tradicionalmente concedidas em excesso e sem um controle efetivo sobre seu potencial de atração de investimentos.

Deve-se reforçar que a implantação de um IVA, em substituição aos tributos hoje incidentes sobre o consumo, enseja a necessidade de revisão dos dispositivos constitucionais concernentes ao condicionamento do repasse do produto da arrecadação, a fim de se assegurar a efetiva transferência dos recursos de um ente a outro. Ademais, o novo modelo deve acompanhar a criação de um sistema de arrecadação ramificado, integrado por todos os 
MORAIS, Maria Laura Clemente; MELLO, Elizabete Rosa de. Federalismo fiscal, autonomia financeira e cooperação federativa: um olhar sobre a possibilidade de instituição de um imposto sobre o valor agregado no Brasil a partir das consequências do "poder de não tributar"

membros da Federação, com o estabelecimento da capacidade tributária ativa de modo compartilhado.

\section{Referências}

ABRAHAM, Marcus. Curso de Direito Financeiro Brasileiro. 5. ed. Rio de Janeiro: Forense, 2018.

AFONSO, José Roberto Rodrigues. (Coord.). A renúncia tributária do ICMS no Brasil. Banco Interamericano de Desenvolvimento (BID). BID, Fevereiro/2014. Disponível em: http://www.gefin.net.br/upload/arquivos/cc16dc55ee89adcd858fff1f6b03e818.pdf. Acesso em: 5 set. 2018.

AFONSO, José Roberto Rodrigues et al. Guerra fiscal do ICMS: Organizar o desembarque. Revista de Direito Internacional Econômico e Tributário, Brasília, v. 12, n. 1, p. 416-443, jan./jun. 2017.

ÁGUIA, José Maurício Pereira. Imposto sobre valor agregado: abordagem teórica e prática. In: SARAIVA FILHO, Oswaldo Othon de Pontes; VASQUES, Sérgio; GUIMARÃES, Vasco Branco (Org.). IVA para o Brasil: contributos para a Reforma da Tributação do Consumo. Belo Horizonte: Fórum, 2007. p. 123-133.

ATALIBA, Geraldo. Sistema constitucional tributário brasileiro. São Paulo: RT, 1968.

BARBOSA, Hermano Notaroberto. O poder de não tributar: benefícios fiscais na Constituição. São Paulo: Quartier Latin, 2012.

BARROSO, Luís Roberto. Parecer n $n^{\circ}$ 01/2009. Sentido e alcance do parágrafo único do art. 160 da Constituição: parâmetros para a retenção de receitas estaduais pela União Federal. Revista de Direito da Procuradoria Geral do Estado do Rio de Janeiro. n. 64, 2010. p. 295-321.

BRASIL. Banco Central do Brasil. Endividamento de Estados e Municípios. Disponível em:

https://www.bcb.gov.br/acessoinformacao/legado?url=https:\%2F\%2Fwww4.bcb.gov.br\%2Ffi s\%2Fdividas\%2Flmunicipios.asp\%3Festado\%3DMG\%26restart\%3D00000000000. Acesso em: 21 ago. 2019.

BRASIL. Conselho Nacional de Política Fazendária - CONFAZ. Convênio ICMS no 190/2017, de 15 de dezembro de 2017. Dispõe, nos termos autorizados na Lei Complementar n 160 , de 7 de agosto de 2017, sobre a remissão de créditos tributários, constituídos ou não, decorrentes das isenções, dos incentivos e dos benefícios fiscais ou financeiro-fiscais instituídos em desacordo com o disposto na alínea " $\mathrm{g}$ " do inciso XII do $\S 2^{\circ}$ do art. 155 da Constituição Federal, bem como sobre as correspondentes reinstituições. Diário Oficial da União, Ministério da Fazenda, Brasília, DF, 18 dez. 2017, Seção 1, p. 78.

BRASIL. [Constituição (1988)]. Constituição da República Federativa do Brasil de 1988. Brasília, DF: Presidência da República, [2020]. Disponível em:

http://www.planalto.gov.br/ccivil_03/constituicao/constituicao.htm. Acesso em: 11 out. 2020. 
MORAIS, Maria Laura Clemente; MELLO, Elizabete Rosa de. Federalismo fiscal, autonomia financeira e cooperação federativa: um olhar sobre a possibilidade de instituição de um imposto sobre o valor agregado no Brasil a partir das consequências do "poder de não tributar"

BRASIL. Governo do Brasil. Entra em vigor lei de recuperação fiscal dos estados. 3 out. 2017. Disponível em: https://www2.planalto.gov.br/mandatomicheltemer/acompanheplanalto/noticias/2017/05/entra-em-vigor-lei-de-recuperacao-fiscal-dos-estados. Acesso em: 30 out. 2018.

BRASIL. Câmara dos Deputados. Emenda Substitutiva Global no 7/2018 à Proposta de Emenda à Constituição no 293-A/2004. Altera o Sistema Tributário Nacional e dá outras providências. Disponível em:

http://www.camara.gov.br/proposicoesWeb/prop_mostrarintegra;jsessionid=365296A6B16B7 E142EA251570719C0D2. proposicoesWebExterno1 ?codteor $=1681042 \&$ filename=Avulso+PEC+293/2004. Acesso em: 30 out. 2018.

BRASIL. Lei $\mathrm{n}^{\circ}$ 5.172, de 25 de outubro de 1966. Dispõe sobre o Sistema Tributário Nacional e institui normas de direito tributário aplicáveis à União, Estados e Municípios. Denominado Código Tributário Nacional pelo art. $7^{\circ}$ do Ato Complementar n 36, de 13 de março de 1967. Diário Oficial da União, Poder Legislativo, Brasília, DF, 27 out. 1966, Seção 1, p. 12451.

BRASIL. Lei no 10.833, de 29 de dezembro de 2003. Altera a Legislação Tributária Federal e dá outras providências. Diário Oficial da União, Poder Legislativo, Brasília, DF, 30 dez. 2003, Seção 1, Edição Extra A, p. 1 (Publicação original).

BRASIL. Lei Complementar $\mathrm{n}^{\circ}$ 24, de 7 de janeiro de 1975. Dispõe sobre os convênios para a concessão de isenções do imposto sobre operações relativas à circulação de mercadorias, e dá outras providências. Diário Oficial da União, Poder Legislativo, Brasília, DF, 9 jan. 1975, Seção 1, p. 345.

BRASIL. Lei Complementar $n^{\circ}$ 87, de 13 de setembro de 1996. Dispõe sobre o imposto dos Estado e do Distrito Federal sobre operações relativas à circulação de mercadorias e sobre prestações de serviços de transporte interestadual e intermunicipal e de comunicação, e dá outras providências. (LEI KANDIR). Diário Oficial da União, Poder Legislativo, Brasília, DF, 16 set. 1996, Seção 1, p. 18261.

BRASIL. Lei Complementar $\mathrm{n}^{\circ}$ 101, de 4 de maio de 2000. Estabelece normas de finanças públicas voltadas para a responsabilidade na gestão fiscal e dá outras providências. Diário Oficial da União, Poder Legislativo, Brasília, DF, 5 maio 2000, Seção 1, p. 1.

BRASIL. Lei Complementar $n^{\circ} 116$, de 31 de julho de 2003. Dispõe sobre o Imposto Sobre Serviços de Qualquer Natureza, de competência dos Municípios e do Distrito Federal, e dá outras providências. Diário Oficial da União, Poder Legislativo, Brasília, DF, 1 ago. 2003, Seção 1, p. 3.

BRASIL. Lei Complementar $n^{\circ} 160$, de 7 de agosto de 2017. Dispõe sobre convênio que permite aos Estados e ao Distrito Federal deliberar sobre a remissão dos créditos tributários, constituídos ou não, decorrentes das isenções, dos incentivos e dos benefícios fiscais ou financeiro-fiscais instituídos em desacordo com o disposto na alínea "g" do inciso XII do $\S$ $2^{\underline{o}}$ do art. 155 da Constituição Federal e a reinstituição das respectivas isenções, incentivos e benefícios fiscais ou financeiro-fiscais; e altera a Lei no 12.973, de 13 de maio de 2014. Diário Oficial da União, Poder Legislativo, Brasília, DF, 8 ago. 2017, Seção 1, p. 8. 
MORAIS, Maria Laura Clemente; MELLO, Elizabete Rosa de. Federalismo fiscal, autonomia financeira e cooperação federativa: um olhar sobre a possibilidade de instituição de um imposto sobre o valor agregado no Brasil a partir das consequências do "poder de não tributar"

BRASIL. Supremo Tribunal Federal. Recurso Extraordinário n 705.423-SE. Recorrente: Município de Itabi. Recorrida: União. Relator: Ministro Edson Fachin. Brasília, 23 nov. 2016. Disponível em:

http://redir.stf.jus.br/paginadorpub/paginador.jsp?docTP=TP\&docID=14291555. Acesso em: 5 set. 2018.

COÊLHO, Sacha Calmon Navarro. Curso de direito tributário brasileiro. 15. ed. Ver. e atual. Rio de Janeiro: Forense, 2016.

COLOMBO, Luciléia Aparecida. Guerra fiscal na federação brasileira: a contribuição das abordagens da sociologia econômica. Revista Sociedade e Estado, v. 32, n. 2, p. 291-311, maio/ago. 2017. Disponível em: http://www.scielo.br/pdf/se/v32n2/0102-6992-se-32-0200291.pdf. Acesso em: 23 out. 2018.

COSTA, Regina Helena. Curso de direito tributário: Constituição e Código Tributário Nacional. São Paulo: Saraiva, 2017.

DALMOLIN, Marcelo Dalton; CARVALHO, Carlos Eduardo. Uma análise institucionalista do pacto federativo fiscal brasileiro. Revista Brasileira de Desenvolvimento Regional, Blumenau, v. 7, n. 3, p. 27-52, 2019. Disponível em: https://proxy.furb.br/ojs/index.php/rbdr/article/view/6326. Acesso em: 09 ago. 2020.

DOMENE, Vanessa. Lei Complementar 160/2017: o fim da guerra fiscal?. JOTA. 2017. Disponível em: https://www.jota.info/opiniao-e-analise/colunas/pauta-fiscal/leicomplementar-1602017-o-fim-da-guerra-fiscal-11082017. Acesso em: 23 out. 2018.

FERRAZ JÚNIOR, Tércio Sampaio. Guerra Fiscal, Fomento e Incentivo na Constituição Federal. In: SCHOUERI, Luis Eduardo (Coord.). Direito tributário: estudos em Homenagem a Brandão Machado. São Paulo: Dialética, 1998, p. 275-285.

GADELHA, Gustavo de Paiva. Isenção tributária: Crise de Paradigma do Federalismo Fiscal Cooperativo. Curitiba: Juruá, 2010.

GUIMARÃES, Vasco Branco. A tributação do consumo no Brasil: uma visão europeia. In: SARAIVA FILHO, Oswaldo Othon de Pontes; VASQUES, Sérgio; GUIMARÃES, Vasco Branco (Org.). IVA para o Brasil: contributos para a Reforma da Tributação do Consumo. Belo Horizonte: Fórum, 2007. p. 37-68.

HARADA, Kiyoshi. Direito financeiro e tributário. 27. ed. São Paulo: Atlas, 2018.

LIZIERO, Leonam; ALCÂNTARA, André Luiz Batalha. Entre a cooperação e a coerção: Como os estímulos institucionais enfraqueceram o sistema federativo brasileiro previsto em 1988. Revista de Direito da Cidade, Rio de Janeiro, v. 12, n. 1, p. 341-365, 2020. Disponível em: https://www.e-publicacoes.uerj.br/index.php/rdc/article/view/40470. Acesso em: 11 ago. 2020.

MARÓN, Manuel Fondevila; TAVARES, Regina Lúcia Gonçalves. Desafios do federalismo fiscal no Brasil à luz de um modelo democrático: Comparação com o modelo americano.

Revista Thesis Juris - RTJ, São Paulo, v. 6, n. 3, p. 438-465, set./dez. 2017. Disponível em: https://periodicos.uninove.br/thesisjuris/article/view/9011/3845. Acesso em: 05 ago. 2020. 
MORAIS, Maria Laura Clemente; MELLO, Elizabete Rosa de. Federalismo fiscal, autonomia financeira e cooperação federativa: um olhar sobre a possibilidade de instituição de um imposto sobre o valor agregado no Brasil a partir das consequências do "poder de não tributar"

MELLO, Elizabete Rosa de. Direito fundamental a uma tributação justa. São Paulo: Atlas, 2013.

MINAS GERAIS. Tribunal de Contas do Estado de Minas Gerais. Relatório Portaria no 80/PRES./2017. Disponível em:

http://www.tce.mg.gov.br/IMG/2017/Sintese\%20Relatorio\%20-

$\% 20$ Portaria\%2080\%20(Versao\%20Final).pdf. Acesso em: 20 out. 2018.

MORA, Monica et al. Finanças Públicas Estaduais. Carta de Conjuntura, IPEA, n. 39, Seção I, $2^{\circ}$ trimestre/2018.

OLIVEIRA, Emerson Ademir Borges de; ROSSIGNOLI, Marisa. Federalismo fiscal no Brasil: da teoria federalista à crise econômica. Revista Jurídica, Curitiba, v. 1, n. 54, jan./mar. 2019, p. 395 - 424. Disponível em:

http://revista.unicuritiba.edu.br/index.php/RevJur/article/view/3315. Acesso em: 5 ago. 2020.

OLIVEIRA, Gustavo da Gama Vital de. Temas de federalismo fiscal brasileiro. Rio de Janeiro: Gramma, 2016.

OLIVEIRA, José Jayme de Macêdo. O ICMS nos Tribunais Superiores. Rio de Janeiro: Autografia, 2016.

PAULSEN, Leandro. Curso de direito tributário completo. 9. ed. São Paulo: Saraiva Educação, 2018.

PISCITELLI, Tathiane. Direito financeiro. 6. ed. São Paulo: MÉTODO, 2018.

PISCITELLI, Tathiane. Reforma tributária pode afrontar pacto federativo. [Entrevista concedida a] Livia Scocuglia. JOTA. 2017. Disponível em: https://www.jota.info/tributos-eempresas/tributario/reforma-tributaria-pode-afrontar-pacto-federativo-24082017. Acesso em: 19 abr. 2019.

RIO DE JANEIRO. Tribunal de Contas do Estado do Rio de Janeiro. Processo no 101.5766/17. Disponível em:

https://www.tce.rj.gov.br/documents/43935520/0/RELATORIO\%20COMPLETO.pdf. Acesso em: 30 out. 2018.

SCHOUERI, Luís Eduardo. Normas tributárias indutoras e intervenção econômica. Rio de Janeiro: Forense, 2005.

TORRES, Ricardo Lobo. É possível a criação do IVA no Brasil? In: SARAIVA FILHO, Oswaldo Othon de Pontes; VASQUES, Sérgio; GUIMARÃES, Vasco Branco (Org.). IVA para o Brasil: contributos para a Reforma da Tributação do Consumo. Belo Horizonte:

Fórum, 2007. p. 19-36. 